$1-1-2015$

\title{
Theorizing Precedent in International Law
}

Harlan G. Cohen

Gabriel M. Wilner/UGA Foundation Professor in International Law and Faculty Co-Director of the Dean Rusk International Law Center University of Georgia, hcohen@uga.edu

University of Georgia School of Law

Research Paper Series

Paper No. 2014-13

Dean Rusk International Law Center

Research Paper Series

Paper No. 2015-09

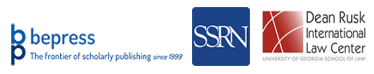

\section{Repository Citation}

Harlan G. Cohen, Theorizing Precedent in International Law (2015),

Available at: https://digitalcommons.law.uga.edu/fac_artchop/1286

This Book Chapter is brought to you for free and open access by the Faculty Scholarship at Digital Commons @ University of Georgia School of Law. It has been accepted for inclusion in Scholarly Works by an authorized administrator of Digital Commons @ University of Georgia School of Law. Please share how you have benefited from this access For more information, please contact tstriepe@uga.edu. 


\section{Theorizing Precedent in International Law}

\section{Harlan Grant Cohen*}

\section{Introduction}

In February 2013, NBC News released a leaked U.S. Department of Justice (DOJ) White Paper on the 'Lawfulness of a Lethal Operation Against a U.S. Citizen Who Is a Senior Operational Leader of Al-Qa'ida or An Associated Force'. The memo, which laid out the U.S. Government's legal reasoning and criteria for such targeted attacks, set off a firestorm of commentary. ${ }^{2}$ Commentators pulled apart the document to understand and critique the Government's position. One thing less noticed - unsurprisingly, given the importance of the substantive debate - was the curious citation to Prosecutor v. Tadic, a decision of the International Criminal Tribunal for the Former Yugoslavia (ICTY). ${ }^{3}$

The citation appears almost as a throwaway, part of an argument by 'some commentators' about the scope of an armed conflict to which the memo-writer is responding. ${ }^{4}$ And yet, it is notable that it appears at all in a 'confidential' memo intended for internal DOJ consumption. Moreover, the framing of the paragraph suggests that the decision does stand for the proposition 'that an armed conflict exists whenever there is ... protracted armed violence between governmental authorities and organized armed groups'. The memo-writer's argument is that the commentators are simply misreading that precedent to find an international law limitation on the scope of armed conflict. The implication is that the Tadic decision is one the U.S. Government needs to know about and needs to be able to distinguish. The commentators' argument about the meaning of Tadic needs to be rebutted.

\footnotetext{
- Associate Professor of Law, University of Georgia School of Law. Thank you to Julian Arato, Jeffrey Dunoff, Rebecca Ingber, Timothy Meyer, and workshop participants at the University of Georgia, University of Washington, Seton Hall University, Bar Ilan University, and the Interdisciplinary CentreHerzilya for helpful comments and suggestions on versions of this project. Thank you also to Amanda McDowell, Lee Deneen, and Dov Preminger for their invaluable research support.

${ }^{1}$ Michael Isikoff, 'Justice Department Memo Reveals Legal Case for Drone Strikes on Americans' (NBCNews.com, 4 February 2013) < http://investigations.nbcnews.com/_news/2013/02/04/16843014justice-department-memo-reveals-legal-case-for-drone-strikes-on-americans?lite> accessed 22 March 2014. See also Department of Justice White Paper, 'Lawfulness of a Lethal Operation Against a US Citizen Who Is a Senior Operational Leader of Al-Qa'ida or An Associated Force' (MSNBCMedia) 4 $<$ msnbcmedia.msn.com/i/msnbc/sections/news/020413_DOJ_White_Paper.pdf $>$ accessed 22 March 2014 (DOJ White Paper).

${ }^{2}$ See, eg David Kaye, 'International Law Issues in the Department of Justice White Paper on Targeted Killing' (2013) 17/8 ASIL < http://www.asil.org/insights/volume/17/issue/8/international-law-issuesdepartment-justice-white-paper-targeted-killing> accessed 23 March 2014; Steve Vladeck, 'What's Really Wrong With the Targeted Killing White Paper' (Lawfare, 5 February 2013) $<$ http://www.lawfareblog.com/2013/02/whats-really-wrong-with-the-targeted-killing-white-paper/> accessed 22 March 2014; Benjamin Wittes \& Susan Hennessey, 'Just Calm Down About that DOJ White Paper' (Lawfare, 5 February 2013) <http://www.lawfareblog.com/2013/02/just-calm-down-about-that-dojwhite-paper/> accessed 22 March 2014.

${ }^{3}$ DOJ White Paper (n 1) 4, citing Prosecutor v Tadic (Decision on the Motion for Interloctuory Appeal on Jurisdiction) ICTY (2 October 1995) para 70.

${ }^{4}$ ibid.
} 
None of this would be surprising if the decisions of international tribunals were, as a matter of doctrine, given precedential weight. But in fact, the opposite has always been the case. International law today, like international law a century ago, generally denies international precedents doctrinal force. Since at least the establishment of the Permanent Court of International Justice in 1922, judicial decisions have been relegated to 'subsidiary means for the determination of rules of law'. This understanding, carried into Article 38 of the Statute of the International Court of Justice ${ }^{6}$ (ICJ) and reified by casebooks and treatises as part of international law's 'doctrine of sources', ${ }^{7}$ has meant that as a matter of international law doctrine, judicial decisions construing international law are not in-and-of themselves law - decisions are not binding on future parties in future cases, even before the same tribunal. ${ }^{8}$ Precedent, as a matter of doctrine, exerts no special force. This is an understanding that states like the United States have strenuously protected. $^{9}$

And yet, as in the DOJ White Paper, the invocation of international decisions as precedent is ubiquitous. Reports from international investment arbitration, ${ }^{10}$ international criminal law, ${ }^{11}$ international human rights, ${ }^{12}$ and international trade ${ }^{13}$ all testify to precedent's apparent authority. Across international law, practitioners invoke it and tribunals apply it. This would be remarkable if courts and tribunals simply cited their own precedent as international law doctrine requires no such result. But courts and tribunals go much farther (following the lead of international advocates), citing positively or negatively even the decisions of other unrelated courts and tribunals emanating from different areas of international law, with different mandates. The precedents from one

\footnotetext{
${ }^{5}$ Statute of the Permanent Court of International Justice art 38(4) (16 December 1920) 6 LNTS 380.

${ }^{6}$ Statute of the International Court of Justice art 38(1)(d) (26 June 1945) 59 Stat 1055, 1060 (ICJ Statute).

${ }^{7}$ See, eg Henry J. Steiner and others, Transnational Legal Problems: Materials and Text (4th edn, University Casebook Series 1994) 232; Lori F. Damrosch and others, International Law: Cases and Materials (4th edn, West Group 2001) 56-57.

${ }^{8}$ ICJ Statute art 38(1)(d), art 59 ('The decision of the Court has no binding force except between the parties and in respect of that particular case'.).

${ }^{9}$ See Brief for the United States as Amicus Curiae Supporting Respondents, Bustillo v Johnson 2006 WL 271823 (US) 30 ('The United States has no obligation to accept the reasoning underlying the ICJ's judgments, however, or to apply that reasoning in other cases'.). The United States has also objected to a doctrine of stare decisis at the WTO. See Doc. (1 July 2008) WT/DSB/M/250 pp $9 \mathrm{ff}$.

${ }^{10}$ See, eg Susan D. Franck, 'The Legitimacy Crisis in Investment Treaty Arbitration: Privatizing Public International Law Through Inconsistent Decisions' (2005) 73 Fordham L Rev 1521, 1611-12; Int'l Thunderbird Gaming Corp v United Mexican States, Final Award, I 129 (26 January 2006), reprinted in (2006) 6 Asper Rev Int'l Bus \& Trade L 419, 571 ('In international and international economic law...there may not be a formal "stare decisis" rule as in common law countries, but precedent plays an important role'.).

${ }^{11}$ See, eg Alexander KA Greenawalt, 'The Pluralism of International Criminal Law' (2011) 86 Ind LJ 1063, 1073-78.

${ }^{12}$ See, eg Christina Binder, 'The Prohibition of Amnesties by the Inter-American Court of Human Rights' (2011) 12 German LJ 1203, 1204.

${ }^{13}$ See, eg Raj Bhala, 'The Myth about Stare Decisis and International Trade Law (Part One of a Trilogy)' (1999) 14 Am U Int'l L Rev 845, 850.
} 
regional body are argued to others, ${ }^{14}$ precedents from human rights courts are argued to investment tribunals, ${ }^{15}$ and precedents from ad hoc criminal tribunals are applied to domestic civil judgments. ${ }^{16}$ The widely-cited Tadic case ${ }^{17}$ referenced in the DOJ White Paper has even made appearances in the decisions of ICSID arbitration panels. ${ }^{18}$ And citations by courts and tribunals can only begin to capture the much wider practice of invoking these decisions in arguments and discussions, formal and informal, over the law's meaning.

So why does an ICTY decision carry weight in internal U.S. Executive Branch discussions? Or in broader terms, when and why do particular decisions become precedents? This chapter begins to answer that question. Its goal is to develop a framework for a broader account of international precedent's emergence. To use this book's metaphor, in the game of international interpretation, what are the spoken and unspoken strategies of precedent? Why will certain prior interpretations be invoked in certain contexts and with certain audiences? When will those strategies be effective, forcing other actors to respond to a prior interpretation, echoing it, building upon it, or distinguishing it?

For the most part, existing discussions of international precedent fail to deal squarely with the question asked here. Many observers have noted the emergence of precedent within particular fields; ${ }^{19}$ some have even opined as to whether that trend is good or bad. ${ }^{20}$ But few have gone further to ask why a system or habit of precedent has emerged in the first place, let alone to explain the varied shapes those systems or habits might take. Other accounts have dealt with the question obliquely, focusing on: (1) Delegation, (2) Compliance, or (3) Strategy. Part II surveys some of these approaches. Although each

\footnotetext{
${ }^{14}$ See, eg Laurence R Helfer, 'Overlegalizing Human Rights: International Relations Theory and the Commonwealth Caribbean Backlash Against Human Rights Regimes' (2002) 102 Colum L Rev 1832 (describing ECHR Soering precedent's migration to other bodies).

${ }^{15}$ See generally Andrea K Bjorklund and Sophie Nappert, 'Beyond Fragmentation' (2010) UC Davis Legal Studies Research Paper No 243, 439 <http://papers.ssrn.com/sol3/papers.cfm?abstract_id=1739997> accessed 22 March 2014.

${ }^{16}$ U.S. courts have, for example, turned to the jurisprudence of the ICTY and ICTR to ascertain the standard for aiding and abetting liability under the Alien Tort Statute, 28 USC $\$ 1350$. Compare Sarei v Rio Tinto PLC 671 F 3d 736 (9th Cir 2011) with Presbyterian Church of Sudan v Talisman Energy Inc 582 F 3d 244 (2d Cir 2009).

${ }^{17}$ Prosecutor v Duško Tadic (Judgment) ICTY-94-1-A (November 1999) 38 ILM 6. See also Harlan Grant Cohen, 'Lawyers and Precedent' (2013) 46 Vand J Transnat'l L 1025 (further describing Tadic's wide dispersion).

${ }^{18}$ International Centre for the Settlement of Investment Disputes Teinver SA Transportes de Cercanias SA Autobuses Urbanos del Sur SA v Argentine Republic (Decision on Jurisdiction and Separate Opinion of Arbitrator Kamal Hossain) ICSID Case No. ARB/09/1; International Centre for the Settlement of Investment Disputes Waguih Elie George Siag, Clorinda Vecchiv Arab Republic of Egypt (Final Award and Dissenting Opinion) ICSID Case No. ARB/05/15. See also Ad Hoc Arbitration (Final Award and Dissenting Opinion) Republic of Italy $v$ Republic of Cuba.

${ }^{19}$ See nn 10-13 and accompanying text.

${ }^{20}$ See, eg Meredith Crowley and Robert Howse, (2010) 'US-Stainless Steel (Mexico)' 9 World Trade Rev 117 (considering stare decisis a valuable development at the WTO); Irene M Ten-Cate, 'The Costs of Consistency: Precedent in Investment Treaty Arbitration' (2013) 51 Colum J Transnat'l L 418, 421 (arguing against precedent in investment arbitration).
} 
captures some aspect of international precedent's story, even considered together, pages - even chapters - seem missing.

Part III starts from the beginning and imagines what a full story of international precedent would need to incorporate. Each of the prevailing accounts focuses on particular moment: a tribunal's creation, a decision whether to comply, or the choice of an advocacy strategy. In each, precedent is a choice. A fuller account of precedent needs to look at international law between those moments, to look at international law as an ongoing, dynamic practice in which precedent is as much a burden as a choice, exerting independent pressure on actors that reframes the choices available to them. (The assumption implicit in each of the prior accounts is that the choice being made has consequences, and that someone, either themselves or another, will be burdened by what they choose.) Using the metaphor of the game, existing accounts focus on individual moves international players make. But those moves only have meaning within the broader strategies players employ and respond to in a larger, longer game. They can only be understood in relation to prior moves and to the game's overall culture(s). Precedent must be understood within the practice of international law.

By focusing on precedent's potential role in international law practice, we can start to tease apart the factors that might contribute to a precedent's emergence. Part III continues by identifying three clusters of factors whose interaction dictate the weight accorded to a particular interpretation of the law: (1) the range of sources that might be treated as precedential in international law; (2) the list of factors that might imbue an interpretation with authority; and (3) the actors who take part in that practice (and judge a source's weight).

Part IV sets those factors in motion and tells three overlapping stories about precedentone jurisprudential, a second sociological, and a third rationalist. It then looks at two examples, official immunity and self-defense against non-state actors, to explore how these three stories interact with one another.

\section{Precedent's Purpose}

Although the presence of precedent in international law is now widely acknowledged, few have sought to explain its emergence, at least not directly. This should be at least somewhat surprising, given the apparent disparity between this reality and the one described by traditional doctrine. Those accounts that touch on the issue tend to focus not on precedent itself, but on other related, but somewhat tangential questions.

\section{Delegation}

Precedent sometimes comes up in discussions concerning the creation of international courts or tribunals and their respective mandates: To what extent have states granted tribunals the power to issue binding judgments, to speak authoritatively with regard to the law they are applying, and to bind future courts that might hear the same or a similar legal issue? Some of these accounts are positivist, starting with the constitutive 
agreement establishing the court and asking what, if anything, those documents say about the force of that court's judgments. In these accounts, precedent is a design feature to be chosen or rejected by a tribunal's designers. Some have read these documents to suggest at least limited forms of horizontal or vertical stare decisis. ${ }^{21}$ In general though, support for precedential force is hard to find in positivist readings of these agreements which, if not denying precedent force (as in the case of the ICJ statute), are silent on the matter. ${ }^{22}$ As a result, these accounts have a hard time explaining the rampant recourse to those tribunal's decisions as precedent.

Other accounts take a more functional approach, asking less what a particular treaty or statute explicitly says than what it implies. These accounts might focus on the structure of a dispute settlement procedure, on the open-endedness of the substantive obligations the tribunal is meant to interpret, or on the presence of third-party rights holders as suggestive of a broader delegation to the tribunal ${ }^{23}$ and to suggest that, from a functional standpoint, the states creating the tribunal must have intended the tribunal to have a certain amount of interpretive authority. Such moves have been used to defend the authority of World Trade Organization (WTO) Appellate Body and European Court of Human Rights (ECHR) decisions. Although these accounts do a better job justifying at least some recourse to precedent in legal argumentation, suggesting that some regimes are designed with precedent in mind, they often rely more on ex ante normative conclusions about precedent's desirability for a particular regime than text or explicit state consent. ${ }^{24}$ Unsurprisingly, their suggestions are often highly contested.

\section{Compliance}

According to some rationalist accounts of courts and compliance, precedent might emerge simply because it is useful. ${ }^{25}$ In some contexts, states may disagree over a particular rule, each preferring a particular interpretation, yet nonetheless prefer coordination to continued disagreement. To the extent third party adjudication can provide a mutually acceptable rule, involving sufficient benefits for each party,

\footnotetext{
${ }^{21}$ Krzysztof J Pelc, 'The Politics of Precedent in International Law: A Social Network Application' (2013) APSA Annual Meeting Paper $<$ http://papers.ssrn.com/sol3/papers.cfm?abstract_id=2299638 $>$ accessed 22 March 2014 (describing the WTO Japan-Alcoholic Beverages II panel's reading of the Dispute Settlement Agreement).

${ }^{22}$ Crowley and Howse (n 20) (describing silence of the WTO Dispute Settlement Understanding and the ICTY Statute). The notable exception is the Rome Statute of the International Criminal Court, art 21.2 (17 July 1998) 2187 UNTS 90 ('The Court may apply principles and rules of law as interpreted in its previous decisions'.).

${ }^{23}$ See, eg Crowley and Howe (n 20) (describing functionalist argument for WTO and ICTY stare decisis); Karen J Alter, 'Agents or Trustees? International Courts in Their Political Context' (2008) 14 Eur J Int'l Rel 33, 38-39.

${ }^{24}$ For example, functionalist accounts often suggest that because human rights treaties are vague and designed to protect third parties, human rights bodies have implicit mandates to fill gaps. See eg, Anthea Roberts, 'Power and Persuasion in Investment Treaty Interpretation: The Dual Role of States' (2010) 104 Am J Int'l L 179, 206-07.

${ }^{25}$ See generally Eric A Posner and John C Yoo, 'Judicial Independence in International Tribunals' (2005) 93 Cal L Rev 1.
} 
continuing to hew to that rule may be desirable. ${ }^{26}$ According to this explanation, precedent is merely epiphenomenal. A precedent's force derives solely from the desirability of the rule reflected in it. Neither its status as the opinion of some body nor its internal reasoning have any independent effect. Although such accounts may explain the stickiness of some international precedents, they have a hard time explaining precedent in non-coordination games like human rights, or why arguments from precedent would have any force when the underlying decision goes against state interests. $^{27}$

\section{Strategy}

Still other accounts consider precedent from the standpoint of strategy. Arguing to a body from its own precedent may make it more favorably inclined to your position. This is true both for advocates to courts or tribunals and for courts or tribunals seeking the support of other courts, something empirical data regarding the European Court of Justice (ECJ), ECHR and national court precedent bears out. ${ }^{28}$ Such accounts bring us closer to understanding precedent's role as advocacy, but they too fail to capture why advocates regularly cite precedents from courts other than the ones they are trying to convince. Perhaps citing other bodies lends prestige, ${ }^{29}$ but this begs the question where such prestige would come from. Why would particular audiences view certain citations in decisions as carrying extra weight? These accounts do suggest some answers in passing, which will be taken up in greater detail below. ${ }^{30}$

A different strategic account treats precedent as soft law. ${ }^{31}$ While the prior strategic accounts focus on the citation to specific decisions, this account looks at the strategic value of creating or promoting a system of precedent. States creating a regime may not be able to get full agreement from each other on rules or interpretations they might favor. Expecting that a tribunal might expand the language of a treaty in favored directions, such states might create a tribunal as a way of legislating rules or interpretations that they

\footnotetext{
${ }^{26}$ See ibid 18.

${ }^{27}$ See generally Laurence R Helfer and Anne-Marie Slaughter, 'Why States Create International Tribunals: A Response to Professors Posner and Yoo' (2005) 93 Cal L Rev 899.

${ }^{28}$ See, eg Laurence R Helfer and Anne-Marie Slaughter, 'Toward a Theory of Effective Transnational Adjudication' (1997) 107 Yale LJ 273; Erik Voeten, 'Does a Professional Judiciary Induce More Compliance?: Evidence from the European Court of Human Rights' [2012] Georgetown University, 4-6 $<$ http://papers.ssrn.com/sol3/papers.cfm?abstract id=2029786> accessed March 22, 2014 (finding decisions rendered by ECHR panels made up of majority professional judges more likely to be complied with than decisions made by panels whose majority hailed from other areas, eg, diplomats, politicians and suggesting this disparity results from the importance of national judges as an audience for ECHR decisions and as compliance agents in enforcing them).

${ }^{29}$ Helfer and Slaughter, 'Effective Transnational Adjudication' (n 28) 325-26 (suggesting that the ECJ and ECHR enhance each other's prestige by citing each other's decisions).

${ }^{30}$ Helfer and Slaughter note that strong reasoning, adherence, and coherence may play a role in the perceived legitimacy of specific decisions. ibid 319-21. In fairness, Helfer and Slaughter examining the attributes of an effective supranational court, not the role of precedent per se.

${ }^{31}$ See generally Andrew T Guzman and Timothy L Meyer, 'International Common Law: The Soft Law of International Tribunals' (2009) 9 Chi J Int'l L 515.
} 
could not achieve by agreement. ${ }^{32}$ From an individual state's point of view, its legal obligations are defined by predictions of what others will consider lawful and unlawful. States reading the tribunal's views will have to take into account the possibility that that decision will be treated as binding law by other states and adjust their calculus and actions accordingly. ${ }^{33}$ Precedent becomes a prediction of what other states might expect a rule to require. This takes us farther towards understanding precedent's weight. What this account fails to explain is why states would expect other states to hold them to the interpretations of that tribunal. A key explanatory cog is missing.

Although each of these accounts tells part of the story of precedent's emergence within international law, even together, they cannot explain the extraordinary pervasiveness of precedent's attraction. There are two (intertwined) limitations to these accounts. First, these accounts are almost entirely and exclusively concerned with the inputs and outputs of international law. Each looks at a particular decision point in international law-the drafting of a treaty, the decision whether to comply, or the choice of arguments to make in a brief or a decision - and attempts to explain why particular actors will or will not support the precedential weight of a decision. Second, in focusing on these decisions, each account is largely rationalist in perspective. It looks at the key actors (mostly states, but sometimes courts) as strategic, rational actors able to see how giving a decision precedential weight might facilitate or impede their goals. It assumes that these actors can and do calibrate precedent's general impact in a regime or how much weight to give a particular potential precedent.

These focuses, however, fail to fully capture how precedent operates within the legal system. The question is not only why states may consciously create a system of precedent, but also why it emerges even when they do not. ${ }^{34}$ The question is not simply why actors choose to invoke certain decisions as precedents, but when and why that choice is effective, when and why that choice carries weight with other actors. Answering these questions requires a broader view of precedent's role within legal argumentation.

Moreover, by focusing on particular actors - the tribunals who claim authority, the actors who decide whether to yield to it, or the actors who invoke it - the accounts are only able to capture a particular angle, a still image of precedent's role. Explaining precedent requires putting these accounts into motion and watching them interact in threedimensions and in 360 degrees. The difference is visible in these accounts' language. Rather than speaking of precedent, they speak of decisions, citations, or compliance. Each depicts a moment in time. But precedent implies a relationship between past, present, and future. An interpretation at one point is imbued with authority at another in the hopes (or fears) that it will be complied with or deemed authoritative in a third.

\footnotetext{
${ }^{32}$ Krzysztof J Pelc argues that WTO member states bring disputes under the Dispute Settlement Understanding less with an eye towards the value of their claim in that case than towards the favorable precedent victory in that case may establish. See Pelc (n 21).

${ }^{33}$ This description highlights the similarity between international law and more sophisticated multiplayer games in which each player must make their moves with an eye on how other players may react to it.

${ }^{34}$ The soft law account recognizes that this may happen and suggests that states may use this reality to their benefit. See Guzman and Meyer (n 31). It does not, however, explain why it happens.
} 
Moreover, precedent's authority is itself dynamic. Whether for philosophical or rationalist reasons, the more a precedent is cited, the more authority it is likely to be given. The reverse is true as well.

\section{Precedent as Practice}

What is needed then is an account not just of the inputs and outputs of the legal process, but of that process itself. What is needed is an account of the practice of international law. ${ }^{35}$ Law does not simply provide rules to be followed. Law also sets norms for discerning, interpreting, advocating, and debating the contents of those rules. It provides spoken and unspoken ground-rules that structure an ongoing claim and response over the applicable law. One party argues for one interpretation of the rules; another argues for a different one. The law frames which arguments are better or worse, which arguments will be convincing, and which will fail.

It is in this sense that the law operates like a game, establishing the rules for making interpretative and argumentative moves. And it is in this game, this practice, that precedents gain their legal force and play their role. Precedent might best be understood as the burden prior interpretations of a particular rule put on future arguments about the content or meaning of the rule. ${ }^{36}$ In its weakest form, precedent simply supplies an argument that one must respond to; one cannot make an argument about the rule's meaning without some reference to why the prior decision is right, wrong, or distinguishable. ${ }^{37}$ In its strongest form, precedent creates a strong presumption that the prior interpretation of the rule is in fact the rule. The question is not why actors do or do not follow precedent, but instead when and why prior interpretations place these burdens on arguments about the rule.

This means that to fully understand how and why interpretations take on weight as precedents, one must understand the process of legal argumentation and the practitioners who take part in it. What sources might those practitioners look to as potential precedents? What are the features of those sources that imbue them with greater or lesser weight in legal arguments? Most of all, who makes up the "community of practice" in a particular area of international law? It is in the interaction of these three factors that a pattern of precedent will emerge.

\section{Source of Precedent}

Although this chapter has so far been concerned primarily with the precedential effect of the decisions of international court or tribunals, there are a wide range of potential sources that actors could invoke as precedents in their arguments. As noted above, a

\footnotetext{
${ }^{35}$ cf Jutta Brunnee and Stephen J Toope, Legitimacy and Legality in International Law: An Interactional Account (Cambridge University Press 2010) 25-26.

${ }^{36}$ Marc Jacob, 'Precedents: Lawmaking Through International Adjudication' (2011) 12 German LJ 1005, 1019 .

${ }^{37}$ ibid 1019 (suggesting that 'deliberately ignoring relevant prior decisions is so arbitrary and artificial a suggestion as to verge on farce').
} 
precedent might be thought of as a prior interpretation of a rule that places some burden on current or future arguments about that rule. Those interpretations can come from a number of places.

First, any number of international court-like bodies might be a source of a precedent. At the most basic level, the prior decision of a particular tribunal might be invoked in current or future arguments before that same tribunal. An ICJ decision might be invoked in a dispute before the ICJ, a WTO Appellate Body decision before the WTO Appellate Body, and so on. As noted above, even this can be controversial. ${ }^{38}$ More fine-grained distinctions might be drawn based on whether the parties or facts are the same in the first and second case, whether the interpretation was part of the holding or dicta in the decision, or whether the claimed precedent came in an advisory opinion or a contentious case. At the next level, decisions by international courts or tribunals with general jurisdiction over international law broadly or an area of international law specifically might be invoked as precedential with regard to that area of law regardless of the forum for the current argument. ICJ judgments might be cited to domestic courts on questions of sovereign immunity, ${ }^{39}$ WTO Appellate Body decisions might be cited to other tribunals on trade law, ${ }^{40}$ ECHR decisions might be invoked regarding human rights, ${ }^{41}$ and ICTY decisions might be invoked with regard to international criminal law. ${ }^{42}$ These precedents might also be extended to closely related, but different areas: ICTY decisions might be invoked as precedents for interpreting domestic statutes, ${ }^{43}$ investment tribunals interpreting one treaty might be used as precedent regarding similar language in another, and one regional human rights body might be invoked before a different one operating under a different treaty. ${ }^{44}$ Finally, at the farthest end of the spectrum, decisions of international tribunals dealing with one issue might be invoked as precedent on an entirely different one, as when human rights decisions are invoked in investment tribunals. ${ }^{45}$ And if all of this extends to advocacy before particular bodies, it extends to all the day-to-day arguments between actors as they try to work out the rules that govern their actions.

In a similar vein, domestic court opinions may be invoked as precedents regarding international law. Examples might include domestic decisions on international criminal

\footnotetext{
${ }^{38}$ See text in Part II.

${ }^{39}$ See text in Part IV.

${ }^{40}$ See, eg Sheng Li, Meng Jia Yang, and Alec Stone Sweet, 'The Institutional Evolution of the InvestorState Arbitration Regime: Judicialization and Governance' (2013) Yale Law School Roundtable Paper $<$ www.law.yale.edu/.../Stone Sweet Lee and Yang Roundtable Paper.pdf > accessed 22 March 2014.

${ }^{41}$ See, eg, Kindler v. Canada (1993) UN Doc CCPR/C/48/D/470/1991 (citing ECHR Soering decision); Pratt v Attorney General for Jamaica, [1994] 2 App Cas 1 (PC 1993) (same).

${ }^{42}$ See, eg Application of the Convention on the Prevention and Punishment of the Crime of Genocide, (Bosn. \& Herz. v. Serb. \& Montenegro) (Judgment) [2007] ICJ 43 <http://www.icjcij.org/docket/files/91/13685.pdf $>$ accessed 22 March 2014 [223] (hereinafter ICJ, Application of Genocide Convention) (deferring to ICTY's findings of fact).

${ }^{43}$ See (n 16).

${ }^{44}$ See Research Report, References to the Inter-American Court of Human Rights in the case-law of the European Court of Human Rights, Council of Europe/European Court of Human Rights (2012), available at www.echr.coe.int/.../Research_report_inter_american_court_ENG.pdff.

${ }^{45}$ See generally Bjorklund and Nappert (n 15$)$ (discussing cases).
} 
liability, ${ }^{46}$ sovereign immunity, ${ }^{47}$ or lethal targeting. ${ }^{48}$ Invoking these decisions as precedent requires attention to whether the decision is really interpreting international law or a related but distinct question of domestic law. ${ }^{49}$ Doctrinally, like the decisions of international bodies, nothing makes these decisions precedential outside their domestic systems. And yet, they are regularly invoked.

But courts and tribunals are not the only potential sources of precedent. Courts and tribunals exist on a spectrum of interpretive bodies, with permanent courts, ad hoc arbitral tribunals, and expert bodies under various treaties. And other international actors with interpretative authority could also be invoked as precedent. To the extent that the International Law Commission or the U.N. General Assembly purport to interpret an existing rule of international law, some may claim that their decisions have authority over about the meaning of that rule. The U.N. Security Council's interpretations of "threat to the peace, breach of the peace, or act of aggression", ${ }^{50}$ as well as its understanding of its power to respond, have been cited in exactly this way. ${ }^{51}$ In fact, U.S. and U.K. arguments for the legality of the Iraq war relied heavily on the "precedents" set by Security Council resolutions from the First Gulf War to that point. ${ }^{52}$ The views of a U.N. Special Rapporteur might be given similar weight. ${ }^{53}$ In some cases, the views of an NGO like the International Committee of the Red Cross (ICRC) might even be invoked.

Finally, state acts might be invoked as precedent. ${ }^{54}$ This is perhaps the oldest source of international precedent. States are interpreting the rules they follow whenever they act. How states customarily act or react may reveal the rule's proper interpretation. ${ }^{55}$ This form of precedent is embodied in both the ICJ Statute's definition of customary

\footnotetext{
${ }^{46}$ See, eg Andre Nollkaemper, 'Decisions of National Courts as Sources of International Law: An Analysis of the Practice of the ICTY' in Gideon Boas and William A Schabas (eds), International Criminal Law Developments in the Case Law of the ICTY (Martinus ijhoff Publishers 2003) 277.

${ }^{47}$ See Jurisdictional Immunities of the State (Germany v. Italy) (Judgment) ICJ Rep 2012, p 99, para 96 (citing national court decisions).

${ }^{48}$ See, eg The Public Committee against Torture in Israel v. The Government of Israel (14 December 2006) HCJ 769/02.

${ }^{49}$ See generally Anthea Roberts, 'Comparative International Law? The Role of National Courts in Creating and Enforcing International Law' (2011) 60 Int'1 \& Comp LQ 57.

${ }^{50}$ Charter of the United Nations, art 39.

${ }^{51}$ See generally Rosalyn Higgins, The Development of International Law Through the Political Organs of the United Nations (Oxford University Press 1963) (considering precedents set by Security Council reactions to the Suez Crisis, the Congo situation, and the North Korean invasion of South Korea);

Jose E Alvarez, International Organizations as Law-Makers (Oxford University Press 2005)184-217.

${ }^{52}$ See, eg William H Taft and Todd F Buchwald, 'Preemption, Iraq, and International Law' (2003) 97 Am J Int'l L 557; Lord Goldsmith, 'Legal Basis for Use of Force against Iraq' (Jeff Weintraub, 17 March 2003)

$<$ http://jeffweintraub.blogspot.com/2003/03/lord-goldsmith-legal-basis-for-use-of.html $>$ accessed 22 March 2014.

${ }^{53}$ For the centrality of Phillip Alston's report on the legality of targeted killings in arguments about the relationship between International Humanitarian Law (IHL) and Human Rights Law, see, eg Kaye (n 2) n7; Ashley S Deeks, 'Unwilling or Unable: Toward a Normative Framework for Extraterritorial Self-Defense' (2012) 52 Va J Int'l L 483, 504.

${ }^{54}$ See Michael Reisman, 'International Incidents: Introduction to a New Genre in the Study of International Law' (1984) 10 Yale J Int'l L 1.

${ }^{55}$ See discussion in Harlan Grant Cohen, 'International Law's Erie Moment' (2013) 34 Mich J Int'1 L 249, 256-57, 270-71.
} 
international law and in the Vienna Convention on the Law of Treaties' invocation of subsequent practice as an interpretive tool for understanding treaties. ${ }^{56}$ The most prominent example might be the invocation of the 1837 Caroline incident between the United States and the United Kingdom as evidence of the standard for legal anticipatory self-defense. ${ }^{57}$

Although any of the above sources could be invoked as precedent, only some will be in any given discussion. Even fewer will actually carry the intended weight with the desired audience. ${ }^{58}$ Which ones will is a function of the next two factors.

\section{Reasons for Authority}

Even within a particular set of sources, some interpretations will carry more weight than others. A variety of factors might influence whether a particular community of practitioners regards a given interpretation as authoritative.

Actors may have self-interested reasons for invoking a particular decision as a precedent. Some of these reasons will be internal to the cited precedent. They may agree with or favor a particular interpretation or may believe that that interpretation has been or will be useful. Other reasons will be external to the decision. They may have some control over the precedent's author (as in the case of arbitration) and trust her decisions. Or they may desire the predictability that hewing to a decision might produce. Alternatively, they may cite decisions that will enhance their prestige. A court might cite another high prestige court in the hope that that other court will cite them in return. They might cite their own decisions (or be open to arguments from their own decisions) in order to enhance their authority over the meaning of particular rules.

But scholars have also identified factors that might exert "compliance pull" independent of outcomes. ${ }^{59}$ The quality of the legal reasoning, the clarity of the interpretation, an interpretation's adherence to prior interpretations, and how well an interpretation fits within a broader legal regime may all be factors internal to a particular decision that may either attract actors to it or burden actors to respond to it. ${ }^{60}$ External to the decision itself, the independence or prestige of the decisionmaker and the frequency of citation to that particular interpretation (discussed more below ${ }^{61}$ ) may exert force on arguments. So too might the relative availability of the source compared to others. An ICJ opinion laying

\footnotetext{
${ }^{56}$ There is a distinction between the use of state practice as evidence of customary international law and as precedent. When used as precedent, it is invoked as authority for an interpretation, rather than an element in a test.

${ }^{57}$ See, eg Anthony Clark Arend, 'International Law and the Preemptive Use of Military Force' (2003) 26 Wash Q 89; Abraham D Sofaer, 'On the Necessity of Pre-emption' (2003) 14 Eur J Int'l L 209.

${ }^{58}$ Andrea Bianchi, The Game of Interpretation in International Law: the Players, the Cards and Why the Game Is Worth the Candle (Draft) at 4 ("The more the discourse is attuned to what the audience needs or wants to hear the greater the speaker's impact on the audience will be.").

${ }^{59}$ See generally Thomas M. Franck, 'Legitimacy in the International System' (1988) 82 Am J Int'l L 705.

${ }^{60}$ ibid.

${ }^{61}$ See text at Part III.
} 
out a rule of customary international law is much easier to cite than all the evidence of state practice and opinio juris that might support a different one.

\begin{tabular}{|l|l|l|}
\hline & Internal Aspects & External Aspects \\
\hline $\begin{array}{l}\text { Outcome } \\
\text { Driven }\end{array}$ & $\begin{array}{l}\text { Success or Potential Success, Agreement } \\
\text { with Interpretation }\end{array}$ & $\begin{array}{l}\text { Control over Decisionmaker, Perceived } \\
\text { Expertise of Decisonmaker, Ability to } \\
\text { Enhance Prestige, Predictability of Future } \\
\text { Results }\end{array}$ \\
\hline $\begin{array}{l}\text { Outcome } \\
\text { Independent }\end{array}$ & $\begin{array}{l}\text { Quality of Legal Reasoning, Clarity of } \\
\text { Rule, Adherence to Prior Interpretations, } \\
\text { Coherence within Broader Legal System }\end{array}$ & $\begin{array}{l}\text { Independence of Decisionmaker, Prestige of } \\
\text { Decisionmaker, Density or Frequency of } \\
\text { Citation, Availability }\end{array}$ \\
\hline
\end{tabular}

Clean lines cannot be drawn between these different types of reasons. Actors may adopt outcome-driven rule-utilitarian beliefs that independent judges produce "better" decisions, or that adherence to prior interpretations is better for the success of a regime they find favorable to their interests even if it sometimes produces decisions they do not like. The complex question precedent raises is how these various factors will balance out when thrown together in real world situations.

\section{Actors and Audiences}

Elsewhere, I have argued that thinking about international law as the product of specific communities of practice can help explain the philosophical, theoretical, and doctrinal differences developing between different areas of international law, as well as the emergence of areas of transnational law almost completely divorced from state control like global administrative law. ${ }^{62}$ Imagining international law as a product of these communities of practice can also help unlock the mystery of precedent.

Precedent is hard to understand as an objective fact disconnected from a particular group of actors. A prior decision by a particular legal body is a fact, but how much weight it should be given in future debates over a particular rule is dependent on how it is perceived by the actors reading it. Precedent is instead an "institutional fact", 63 Like a "hit" or a "strike" in baseball, it is only a fact within the particular rules of a particular institution or community. ${ }^{64}$ Just as a student of baseball and a student of cricket will see two very different sets of facts in a group of people with bats and ball on a field, so too will actors biased towards the authority of courts or the bindingness of precedent perceive the value of a tribunal decision differently than actors biased towards state consent and pragmatism.

Different international law regimes - international human rights law, international humanitarian law, international investment law, international environmental law, or

\footnotetext{
${ }^{62}$ See generally Harlan Grant Cohen, 'Finding International Law, Part II: Our Fragmenting Legal Community' (2012) 44 NYU J Int'l L \& Pol 1049.

${ }^{63}$ Friedrich V Kratochwil, Rules, Norms and Decisions: On the Conditions of Practical and Legal Reasoning in International Relations and Domestic Affairs (Cambridge University Press 1989) 22-28. See also John Ruggie, 'Epistemology, Ontology, and Regimes' in John Gerard Ruggie (ed), Constructing the World Polity (Routledge 1998) 90-91.

${ }^{64}$ ibid 91, quoting John Rawls, 'Two Concepts of Justice' (1955) 64 Phil Rev 3, 25.
} 
international criminal law-involve different mixes of actors-advocates, political leaders, diplomats, military personnel, scientists, economists, international lawyers, and domestic lawyers. ${ }^{65}$ Each of these different actors brings their own professional norms and biases to the debate, and different mixes of actors will agree on different norms and operating assumptions. Understanding the relative weight different decisions by different bodies carry in different contexts requires understanding the communities of actors who might perceive them that way. ${ }^{66}$ The key is identifying the actors who practice in a particular area of law, both at the center of that practice, interacting regularly and intensely over the meaning of rules, and at the periphery. ${ }^{67}$ These are the players in international law's interpretative game. ${ }^{68}$

The actors listed above are, of course, only archetypes. Real-world actors wear multiple hats at the same time or over time. A government lawyer may go into private practice or become a judge, a politician may be a trained lawyer, and a lawyer may be a member of the military. These archetypes though allow us to isolate characteristics, habits, biases, or incentives that shape the international legal practice in which they engage. Moreover, identifying specific types of actors allows us to group them in ways that help us to understand how they interact with particular potential legal sources and answer legal questions. Thus we might group actors by professional training, grouping together lawyers, economists or scientists. Or we might group them within epistemic communities, asking who they interact with in their issue areas: military professionals, business leaders, or diplomats. Alternatively, we might group them based on their social and political capital or incentives. How is success in their job defined and who defines it? Even if all trained as lawyers, politicians, bureaucrats, NGO activists, judges, and military lawyers may all respond to different incentives and may look to different audiences for career or personal advancement. Finally, we might group them according to their function and relationship to precedent: Are they advocating, judging, administering, or seeking guidance for action?

Importantly, we also need to look at these various actors as both actors and audiences. We need to understand not just why those who reference a precedent might find it weighty, authoritative, or even binding, but also why the audience that reference is aimed at might as well. In other words, we need to know why a lawyer assessing policy options or advocating a position might feel the need to cite a particular reference, as well as why her intended audience, whether policymakers, judges, or opposing lawyers, might

\footnotetext{
${ }^{65}$ Each of these groups could be divided into increasingly small subgroups. Lawyers, for example, might be divided into domestic and international lawyers, government and private practice lawyers, public interest and private lawyers, litigators and transactional attorneys, not to mention lawyers working or trained in different legal cultures and different parts of the world.

${ }^{66}$ See generally Cohen (n 62); Bianchi (n 58) 13.

${ }^{67}$ Bianchi (n 58) 4 (describing the 'audience' for interpretative arguments as 'those individuals who participate, watch or have stakes in the game'). For a fuller discussion of how communities of practice are structured, see Cohen (n 62) 1065-69, 1089-90 (building off the work of Emanuel Adler and in particular, Emanuel Adler, Communitarian International Relations: The Epistemic Foundations Of International Relations (Routledge 2005)).

${ }^{68}$ Bianchi (n 58) 8-9 (describing the players in the 'interpretative community').
} 
respond favorably to it. ${ }^{69}$ We might think of this as first person and second person points of view on the weight of a given precedent. Different factors may speak more to one than the other. Both the legitimacy-pull of treating like cases alike and training in legalanalogical reasoning may generate first-person reasons to cite a precedent; a belief that judges might respond favorably to citations of court opinions or that policymakers will respond favorably to anecdotes about prior state actions would generate second-person ones. In reality, because all of the actors making and responding to arguments operate within an ongoing, iterative practice, the lines between the two are impossible to draw. Conceptions of authoritative sources are constantly being constructed through the interaction of the various actors. Legal arguments are inherently relational; they are attempts by one actor to convince another actor to act in a particular way. An advocate must predict how other advocates and judges will respond to their argument; a judge must predict how lawyers and policymakers will respond to theirs. First and second-person points of view merge.

\section{Telling Precedent's Story}

The ingredients discussed in Part III-sources, features, actors - can be combined to tell three intertwined stories about the emergence of international precedent, one rationalist, one jurisprudential, and one sociological.

\section{A Rationalist Account}

Under this account, interpretations should be invoked or treated as precedent when doing so helps achieve various actors' broader goals. Such an account largely tracks existing explanations for precedent described earlier. ${ }^{70}$ For a state actor, this may mean citing a precedent that supports a position a state wants to take or that a court might predictably favor (for example, one of that court's own prior decisions). For the judge, it might mean citing a precedent from a court it is trying to convince or citing its own decisions to solidify its control over interpretation.

But such a rationalist story could also explain why states might support a broader system of precedent, even when doing so may not always favor their desired positions. To the extent states are invested in a particular regime, predictability may be valuable enough for them to support precedent-based arguments generally. This is true whether the potential precedents are found in state actions or in judicial opinions. To the extent thirdparty decisionmaking is capable of resolving difficult coordination problems, states may give a court or tribunal's decision precedential force in order to preserve that court or tribunal's authority in the regime. ${ }^{71}$ (Questioning that body's decisions too often might

\footnotetext{
${ }^{69}$ One question an actor making an argument must at least implicitly ask is whether a particular argument will actually engage their opponent, forcing them to respond to it, even if to argue against it. An argument that an opponent must respond to can limit that opponent's options and frame an argument in a way favorable to the one making the argument. An argument that the opponent does not see as weighty or authoritative can simply be laughed off or ignored, and may have little impact.

${ }^{70}$ See text in Part I.

${ }^{71}$ One could look at the citation to precedent as akin to an iterated prisoner's dilemma. Each side will continue to cooperate so long as the other side continues to cooperate. Citing precedents might signal a
} 
undermine that body's authority.) Moreover, treating prior decisions as precedential might add desirable clarity to the rules. To the extent states value general clarity more highly than winning the cases precedent might cost them, states should support precedent. $^{72}$

Of course, few (if any) regimes explicitly provide for precedential effect. This suggests that for the states designing those regimes, the optimal level of clarity and predictability is greater than a system of de novo review but less than one of stare decisis. Denying the force of precedent, while nonetheless arguing from it, may be a way of calibrating precedent's exact weight. Assuming that arguments from precedent will have some natural force (see the next story), this strategy could allow states to take advantage of the predictability of precedent, while still retaining some room to argue against a precedent's relevance in a particular case. The danger of this strategy, as demonstrated by the precedent-creep in the WTO, ECJ, and ECHR, is that if every state uses this strategy, precedent-based arguments are likely to predominate. Even if one state has an interest in flexibility in a given case, states, in the aggregate, are likely to favor predictability over flexibility, and a de facto doctrine of precedent will likely emerge. ${ }^{73}$ This is reinforced by the normative power of oft-cited precedent (discussed below), which may make erasing the prior interpretation nearly impossible.

\section{A Jurisprudential Account}

But all of this assumes that when an argument is made that a prior interpretation dictates a current one, that argument carries some independent additional weight and has some authority beyond the reasoning attached to it. Under the rationalist account, this extra weight may just reflect an implicit understanding of the system-value of precedents for achieving the relevant actor's goal. But from a jurisprudential standpoint, it might be that the authority of precedents inheres in legal argumentation.

Precedents carry whatever weight or authority they have within a legal argument. As noted above, precedent might best be seen as the burden a prior interpretation of a rule places on future arguments about that rule. In the absence of any prior interpretation, an interpreter has a lot of latitude to choose a particular interpretation of a rule. Evidence of a prior interpretation seems to change that equation. As a matter of reasoned legal argument, such an interpretation cannot be ignored. Depending on a variety of factors that might give the prior interpretation greater legal authority - the prestige of the prior interpreter, the quality of the legal reasoning behind it, its perceived adherence to other prior interpretations or coherence within the system - that decision might be brushed aside, distinguished, narrowed, adopted, or extended, but it must be dealt with. Failing to

\footnotetext{
continued commitment to cooperation within the regime. Failure to cite a precedent, or undermining a precedent, might signal an unwillingness to cooperate. Other states may "punish" the act, by questioning other precedents they do not like. See Robert Axelrod, The Evolution of Cooperation (Basic Books 1984) (explaining how in an ongoing 'game', cooperation can emerge).

${ }_{73}^{72}$ See generally Pelc (n 21).

${ }^{73}$ For a discussion of how the increased frequency of judicial decisionmaking and the expanding web of international judicial bodies increases the strength of precedent in ways that the ICJ Statute's drafters likely could not have foreseen see Cohen (n 55) 276-80.
} 
do so might be seen as arbitrary and a violation of rule of law norms. ${ }^{74}$ This effect is compounded the more the particular prior decision is considered and cited. ${ }^{75}$ The greater the frequency of citation, the harder it is to ignore the decision, and the greater the burden on current interpretation. ${ }^{76}$

Moreover, the discursive power of precedent may have normative force. Common to many theories of law is a view that one of law's core principles or qualities is that it treat like situations alike. Lon Fuller describes consistency as part of the internal morality of law, ${ }^{77}$ Ronald Dworkin's law as integrity denies the legitimacy of checkerboard laws that treat like cases differently, ${ }^{78}$ and Tom Franck describes coherence and adherence as key factors in the perceived legitimacy of laws. ${ }^{79}$ From this standpoint, precedent's pull can be seen as a direct articulation of rule of law norms. If like cases must be treated alike, future decisions must at least make reference to prior ones. ${ }^{80}$

A related jurisprudential argument often made in support of precedent is reliance, that law must protect the reasonable expectations of the governed. ${ }^{81}$ It might seem bizarre to suggest that states have a reliance interest in the decisions of international tribunals that they have so deliberately denied precedential effect, but such arguments are sometimes made. $^{82}$ (States are more likely to argue that they relied on the precedent set by prior state acts than a prior tribunal decision. ${ }^{83}$ ) More often, the argument about reliance on prior decisions is made on behalf of individuals rather than states, either in the human rights or investment protection context. It is essentially an argument against state prerogative. Invocation of the legality principle in the international criminal context may contain a version of this argument. Some notion that individuals should be able to rely on the prior decisions of international criminal courts may explain why the International Criminal Court is the sole international court authorized by treaty to look to its prior decisions as a source of law. ${ }^{84}$

\footnotetext{
${ }^{74}$ See Jacob (n 36).

${ }^{75}$ A doctrinal example of this can be seen in the concept of jurisprudence constante in some civil law systems. See, eg Mary Garvey Algero, 'The Sources of Law and the Value of Precedent: A Comparative and Empirical Study of a Civil Law State in a Common Law Nation' (2005) 65 La L Rev 775, 787-92.

${ }^{76}$ Cohen (n 55) 276-280.

${ }^{77}$ See generally Lon L Fuller, The Morality of Law (Yale University Press1964). See also Edwin W Tucker, 'The Morality of Law, by Lon L. Fuller' (1965) 40 Ind LJ 270, 274 (book review).

${ }^{78}$ Ronald Dworkin, Law's Empire (Harvard University Press 1986) 176-224.

${ }^{79}$ Thomas M Franck, 'Legitimacy in the International System' (1988) 82 Am J Int'l L 705, 712.

${ }^{80}$ See Helfer \& Slaughter, 'Effective Transnational Adjudication' (n 28) 319-20 ('In a social or legal culture that venerates tradition for its own sake, consistency with earlier decisions provides an autonomous bulwark of legitimacy'.).

${ }^{81}$ See generally Hillel Levin, 'A Reliance Approach to Precedent' (2012) 47 Ga L Rev 1035.

${ }^{82}$ See WTO, Japan-Alcoholic Beverages (4 October 1996) WT/DS8/AB/R and WT/DS10/AB/R, WT/DS11/AB/R [14]. ('Adopted panel reports...create legitimate expectations among WTO Members, and, therefore, should be taken into account where they are relevant to any dispute'.).

${ }^{83}$ This might be thought of as a version tu quoque, but one used not as an excuse but as a positive legal argument. A good example might be Russia's open invocation of NATO policy to Kosovo as precedent for its actions in Georgia.

${ }^{84}$ Rome Statute of the International Criminal Court (adopted 17 July 1998) 2187 UNTS 90 art 21.2 ('The Court may apply principles and rules of law as interpreted in its previous decisions'.).
} 
Whether the argument is about treating like cases alike or concerns about reasonable reliance, these jurisprudential arguments suggest that it is the most proximate and similar decisions - from the same body or actors or on the same issue - that will carry the most weight. The easier it is to distinguish the context, the less weight an interpretation will carry. It also suggests that the less clear the precedent and the more ad hoc the interpretation appears to be, the easier it will be to distinguish. This helps explain why judicial interpretations, which are usually clearer and nested within a body of jurisprudence, seem to become precedents so much more rapidly than interpretations derived from state practice, which are often purposely ambiguous. ${ }^{85}$

\section{A Sociological Account}

But for this jurisprudential account to have force, someone must actually believe in it or have some other incentive to abide by it. ${ }^{86}$ Nor can the jurisprudential account on its own choose between different sources of precedent. Prior interpretations might have weight, but which ones: judicial opinions, state practice, expert reports? It is here that a sociological account of the actors who invoke and respond to arguments from precedent becomes essential. This sociological account has so far been neglected in the literature on international precedent, but it is this account that provides the key to understanding the operation and effectiveness of the other two. It explains why invoking precedent selfinterestedly may get a response and why the jurisprudential account may exert some independent pull. In essence, the sociological account provides the context of the game in which precedent-based moves will either succeed or fail.

Specific actors may be trained to see certain sources an authoritative. Lawyers, particularly those trained in a common law tradition, are trained to seek out, read, and argue from judicial decisions. ${ }^{87}$ Members of the military may be trained to look to historical combat actions for lessons. Specific actors may also belong to professional communities that respond to those sources or expect reference those sources. Lawyers, for example, might experience professional opprobrium or sanction for failing to cite relevant precedents. And different actors may face a range of social and political incentives to cite particular sources. Politicians, for example, will have incentives to cite precedents that will help sway voters in their favor. ${ }^{88}$

Take the example of lawyers very generally. Lawyers are indoctrinated with rule of law principles, principles which, in turn, are embodied in legal professional ethics. To the extent they work with other lawyers, particularly domestic lawyers, they may be expected to argue from judicial precedent. Within a legal organization, arguments that follow the

\footnotetext{
${ }^{85}$ See Cohen (n 55) 257-71 (describing the different features of gap-filling through negotiation and gapfilling through adjudication, including the latter's relative clarity, speed of development, and pathdependence).

${ }^{86}$ See Bianchi (n 58) 4 ('It suffices to say here that rhetorical tools and argumentation techniques that resonate deeply with international lawyers and other social agents engaged in the game are likely to be a very important component of a successful strategy'.).

87 ibid 9 .

${ }^{88}$ See generally Katerina Linos, The Democratic Foundations of Policy Diffusion: How Health, Family, and Employment Laws Spread Across Countries (Oxford University Press 2013).
} 
professional script and reference judicial precedents will be rewarded. Arguments that seek to be overly creative or iconoclastic might not. Given their skill sets, judicial precedents may be more readily available to them than other sources.

Most of all, when working with non-lawyers, arguments from judicial precedent may enhance the lawyer's stature. Lawyers as a professional group have specific sources of political and social capital that they can use to maintain their importance and relevance in relation to other societal actors. ${ }^{89}$ Among these is lawyers' purported expertise in interpreting and applying complex legal sources. Lawyers, seeking to maximize their own power and authority vis-à-vis other international actors, will want to emphasize the value of precedents and their unique ability to understand them.

In other words, lawyers at the U.S. State Department or Defense Department may argue that precedents need to be followed (a) because they believe that rule of law requires it, (b) because they fear formal or informal professional or group sanction (i.e., shunning) if they fail to adhere to it, or (c) because arguing for precedent reinforces their authority within decisionmaking circles. ${ }^{90}$ One need not choose between these reasons; they reinforce one another.

Of course, the actual story is much more complicated. Lawyers are not all the same. Hailing from different parts of the world, they may have been trained differently. They may belong to different organizations with different organizational cultures, priorities, and scripts. A lawyer in a foreign ministry may see the world differently from a military lawyer or a lawyer at the ICRC. ${ }^{91}$ Or they may belong to different epistemic communities. $^{92}$ The results of these differences, including how lawyers interact with other actors in a community of practice, may go a long way towards explaining different patterns of precedent or different ways of arguing from precedent in different areas of international law. ${ }^{93}$ Scholars have only begun to study the sociology of these actors. ${ }^{94}$ Much more work needs to be done.

\footnotetext{
${ }^{89}$ See generally Pierre Bourdieu, 'The Force of Law: Toward a Sociology of the Juridical Field' (1987) 38 Hastings L 805; Yves Dezalay and Bryant G Garth, Dealing in Virtue: International Commercial Arbitration and the Construction of a Transnational Legal Order (University of Chicago Press 1998) (applying Bourdieu's insights and describing the "field" of international commercial arbitration).

${ }^{90}$ cf Rebecca Ingber, 'Interpretation Catalysts and Executive Branch Legal Decisionmaking' (2013) 38 Yale J Int'l L 359.

${ }^{91}$ As David Luban writes: 'Organizational cultures are interpretive communities; lawyers in them develop their own lore about what the law means and how to read it'. David Luban, 'Military Necessity and the Cultures of Military Law' (2013) 26 Leiden J Int'l L 315, 318.

${ }^{92}$ See generally ibid (describing cultural differences between IHL lawyers and military lawyers); Kenneth Anderson, 'The Rise of International Criminal Law: Intended and Unintended Consequences' (2009) 20 Eur J Int'l L 331 (describing divergence between epistemic communities of international criminal law and military law). See also Bianchi (n 58) 23 ('There is no doubt that the "living instrument" or "evolutive interpretation" doctrines resonate better in human rights circles, when it comes to interpreting broadly states' human rights obligations'.).

${ }^{93}$ Courts too may have different biases and approach precedents differently. The ICJ, with jurisdiction only over consenting states and staffed by judges with strong state-connections, is likely to be more conservative and hew more closely to state practice than an international criminal tribunal, with its broad mandate to bring perpetrators to justice and justice to victims, a human rights court delegated responsibility under a human rights treaty, or a domestic court that may be more experienced in redressing individual
} 


\section{Three Accounts in Action}

As a very general matter, these three stories reinforce one another, making the turn to precedent in legal argumentation somewhat over-determined. In specific cases, however, they may point in different directions. Two examples may usefully demonstrate this.

\section{Foreign Official Immunity}

In a search of briefs submitted on behalf of the U.S. State Department Legal Adviser in cases before U.S. courts, one citation stands out. The Legal Adviser regularly cites the ICJ's Arrest Warrant decision ${ }^{95}$ as precedent regarding questions of foreign official immunity. ${ }^{96}$ Given that the United States would likely object to any claim that ICJ judgments are authoritative statements of the law, the citation to an ICJ judgment as precedent by the U.S. government to a domestic court might need some explanation.

Citation to the Arrest Warrant case, however, should hardly be surprising. Every factor seems to support it. From a sociological standpoint, those authoring the brief are practicing attorneys trained to look to precedent. The arguments are, in turn, being made to American judges habituated to arguments based on judicial precedent and habituated to respect other judges. Those making the arguments belong to an organizational culture (the State Department) particularly attuned to sovereign immunity and its role in avoiding friction between states. They represent the United States before the ICJ and might be more likely than other parts of the government to view that court's judgments as important. The decision is far easier to cite than the evidence of custom underlying it.

rights violations than in considering the interests of the collectivity of sovereign states. This might explain the disagreements between the ICJ and other courts and the ICJ's more conservative approaches to state attribution and sovereign immunity. See, eg ibid 5-6 (discussing the ICJ's decision in Jurisdictional Immunity of States).

${ }^{94}$ Building on the work of Pierre Bourdieu, a series of scholars including Bryant Garth, Yves Dezalay, and Mikael Rask Madsen, have begun to study the sociology of lawyers operating in different fields and in different countries, examining their training, their culture, and the social and political capital they wield in particular political system. See Garth and Dezalay (n 89). See also Yves Dezalay and Bryant G Garth, The Internationalization of Palace Wars: Lawyers, Economists, and the Contest to Transform Latin American States (University of Chicago Press 2002); Yves Dezalay and Bryant G Garth, Asian Legal Revivals: Lawyers in the Shadow of Empire (Chicago University Press 2010); Yves Dezalay and Mikael Rask Madsen, 'The Force of Law and Lawyers: Pierre Bourdieu and the Reflexive Sociology of Law' (2012) 8 Ann Rev of L and Soc Sci 433. International law scholars have barely begun to plumb this work, let alone embark on it themselves.

${ }^{95}$ Case Concerning the Arrest Warrant of 11 April 2000 (Democratic Republic of Congo v. Belgium) [2002] ICJ 3.

${ }^{96}$ See, eg Brief for Appellees, Yousuf, v Samantar, 2011 WL 5040507 (4th Cir 24 October 2011) (No 111479); Brief for Appellee, Giraldo v Drummond Company Inc 2012 WL 3152126 (DC Cir 3 August 2012) (No 11-7118); Brief for Appellee, Habyarimana v Kagame 2012 WL 1572450 (10th Cir 30 April 2012) (No 11-6315). The typical brief reads simply: 'Under customary international law principles accepted by the Executive Branch, a sitting head of state's immunity is based on his status as the incumbent office holder, and it extends to all of his actions, whenever performed'. Case Concerning the Arrest Warrant of 11 April 2000 (Democratic Republic of Congo v Belgium) (Judgment) [2002] ICJ Rep 3, pp 21-22." Brief in Habyarimana (n 96). In the same way that a U.S. Supreme Court decision might be used, the Arrest Warrant case is invoked as authority for the proposition. 
From an organizational standpoint, once the decision has been made to cite the ICJ judgment, lawyers are likely encouraged to cite to it again rather than revisit the question.

From a jurisprudential standpoint, the practice before courts is relatively dense in the area of sovereign immunity, augmenting the authority of judicial decisions. Whether one can be sued in a particular court is by its nature a question courts will be forced to decide, and sovereign immunity questions make common appearances not only in U.S. courts, but in other domestic and international courts. Moreover, as the Arrest Warrant case continues to get cited, its precedential force is magnified. The citation becomes more obvious and harder to ignore without violating legal or ethical norms.

Finally, from a rationalist perspective, lawyers in the Legal Adviser's office can be assumed to be channeling the rational self-interest of the U.S. when they cite the Arrest Warrant case. The U.S. has long been invested in protecting official immunity, not least because the U.S. wants its officials protected overseas. ${ }^{97}$ Maintaining official immunity for its own officials requires guaranteeing it to foreign ones, and doing so requires monitoring the courts to guarantee against accidental violation. In a sense, the grant of foreign official immunity might be seen as the product of an iterated prisoner's dilemma; cooperation is maintained so long as neither side cheats. Moreover, the U.S. has an interest in promoting the authority of the ICJ judgment as a coordination point with other states and a source of clarity and predictability regarding the law.

\section{Self-Defense Against Non-State Actors}

But this consensus around a precedent or precedents breaks down when the question is the legality of the use of force by one state against non-state actors in another. Here the factors point in different directions. The three stories above (rationalist, jurisprudential, sociological) sound different when read by different actors.

Whether a state can respond with force to a terrorist or insurgent attack emanating from another state has become a contentious issue. ${ }^{98}$ The text of the U.N. Charter leaves room for interpretation. Although Article 2(4) requires all member states to 'refrain in their international relations from the threat or use of force against the territorial integrity or political independence of any state', 99 Article 51 preserves states' 'inherent right of individual or collective self-defence' if an armed attack occurs against them. ${ }^{100}$ Does an attack by a non-state actor implicate a state's right to self-defense? Does that right allow targeted states to violate other states' sovereignty, otherwise protected by Article 2(4), to counter the threat? If so, under what conditions?

\footnotetext{
${ }^{97}$ In some of these briefs, the self-interest is even more obvious, particularly where the Arrest Warrant case is cited for the proposition that foreign official immunity belongs to the state rather than the official. See, eg Giraldo Brief (n 96) 22; Samantar Brief (n 96) 6.

${ }^{98}$ Situations raising this question include attacks in Kenya from Al-Shabab in Somalia, attacks against the United States by Yemen-based Al Qaeda in the Arabian Peninsula (AQAP), attacks in Colombia by the FARC forces based in Ecuador, and Hezbollah attacks from Lebanon into Israel.

${ }^{99}$ Charter of the United Nations (24 October 1945) 1 UNTS 16 (UN Charter) art 2(4),

100 ibid art 51.
} 
Answering these questions has become a war over precedents. For some human rights and international humanitarian law scholars ${ }^{101}$ the ICJ already answered these questions in its Nicaragua, Israeli Wall, and Democratic Republic of Congo (DRC) v. Uganda opinions. ${ }^{102}$ In each case, the court at least implied that self-defense is only possible against a state and that reprisals against non-state actors in a foreign state are lawful only when the non-state actors' actions are attributable to that state. ${ }^{103}$ As far as these scholars are concerned, these decisions are authoritative precedent.

But U.S. government lawyers (among others) disagree. ${ }^{104}$ For them, these ICJ interpretations are mere dicta. Instead, they look to a different source of precedent, state practice. ${ }^{105}$ What they find there is a common standard: when a non-state actor's actions against a state rise to the level of an armed attack, a targeted state's right to self-defense attaches, and where the host state is 'unwilling or unable' to prevent the threat, the targeted state may use force within the host state's borders to counter the non-state actor. This is, in fact, part of the argument in the DOJ White Paper on targeted killing discussed above. $^{106}$

We can see how, under the circumstances, the accounts above may not yield a single answer here or coalesce around the authority of a single line of precedent. Different factors cut in different directions. On the one hand, the cited decisions emanate from an independent and prestigious international court, the ICJ. ${ }^{107}$ And the state practice underlying the 'unwilling or unable' standard is clearly biased in favor of those states

101 eg Tom Ruys, 'Armed Attack' and Article 51 of the UN Charter: Evolutions in Customary Law and Practice (Cambridge University Press 2010) 475-76; Kevin Jon Heller, 'The Law of Neutrality Does Not Apply to the Conflict with Al-Qaeda, And It's a Good Thing, Too: A Response to Chang' (2011) 47 Tex Int'l LJ 115, 140; Mary Ellen O'Connell, 'Remarks: The Resort to Drones under International Law' (2011) 39 Denv J Int'l L \& Pol'y 585, 594-95.

${ }^{102}$ Case Concerning Military and Paramilitary Activities in and Against Nicaragua (Nicaragua. v US), (Merits) [1986] ICJ 14 (Nicaragua); Legal Consequences of the Construction of a Wall in the Occupied Palestinian Territory (Advisory Opinion) [2004] ICJ 136 (Israeli Wall); Case Concerning Armed Activities on the Territory of the Congo (Democratic Republic of the Congo v Uganda), (Judgment) [2005] ICJ 168 (DRC).

${ }^{103}$ The ICJ in Nicaragua (n 102) 103-104, faced with the question of whether the actions of a non-state group could be an "armed attack" triggering self defense, focused on whether the non-state actor's actions could be attributed to a state, developing a test of "effective control." In the Israeli Wall advisory opinion (n 102) 192-194, the ICJ held that Israel could not invoke self-defense because Israel did not allege that the acts were imputable to a foreign state and 'Article 51 of the Charter...recognizes the existence of an inherent right of self-defence in the case of armed attack by one State against another State'. And in the $D R C$ opinion (n 102) 222-223, despite declining to address 'whether and under what conditions contemporary international law provides for a right of self-defence against large-scale attacks by irregular forces', the ICJ held that attacks in question did not trigger Uganda's right to self-defense because they were 'non-attributable to the DRC'.

${ }^{104}$ See generally Deeks (n 53); Steven R Ratner, 'Self-Defense Against Terrorists: The Meaning of Armed Attack,' in Nico Schrijver and Larissa Van den Herik, The Leiden Policy Recommendations on Counterterrorism and International Law, $1<\mathrm{http}$ ://papers.ssrn.com/sol3/papers.cfm?abstract id=2047778> accessed 22 March 2014; Theresa Reinold, 'State Weakness, Irregular Warfare, and the Right to SelfDefense Post-9/11' (2011) 105 Am J Int'l L 244.

${ }^{105}$ See generally Deeks (n 53).

${ }^{106}$ See DOJ White Paper (n 1) (citing historical precedents).

${ }^{107}$ See Bianchi (n 58) 10-11 (noting the 'official' status of ICJ opinions with international lawyers). 
responding to such threats. On the other hand, the ICJ's views are arguably dicta and certainly are not fully explained in the opinions. One of the opinions arose out of the court's advisory jurisdiction, suggesting that its views might be less binding. Both sides argue that the other's precedents are too few and uncertain to be authoritative. ${ }^{108}$ The ICJ decisions might predict what a future international court might hold, but the practice of the states surveyed arguably predicts what states will actually treat as lawful or unlawful. And of course, from a self-interested angle, the two sides clearly favor different answers, answers that find support in different potential precedents.

Moreover, unlike foreign official immunity, these use of force issues are not frequently before courts. There is no thick judicial practice on the issue. Instead, the real practice on this issue takes place around two separate nodes: human rights advocacy and state national security policy. Rather than a single line of precedent gaining force by repeated citation, two lines of precedent gain force as they are repeatedly cited in particular fora and among particular practitioners.

Lawyers are involved on both sides, and notably, lawyers on both sides of the debate appeal to precedent, reflecting both the expectations of a lawyerly community and precedent's normative and discursive power. But the lawyers involved on either side belong to different professional, organizational, and epistemic communities. They may have different biases about how to interpret use of force questions, ${ }^{109}$ and are subject to very different social and professional incentives. The incentives for a human rights advocate or a professional scholar are obviously quite different than those for government and, in particular, military attorneys embedded within state agencies and the chain of command.

\section{Conclusion}

Precedent is part of the spoken and unspoken strategies of international law interpretation. Whether realizing it or not, international actors, the players in the interpretative game, invoke or respond to particular precedents as part of a broader effort to justify their positions and persuade other players to go along with them. This chapter has sought to understand how those strategies emerge and evolve, and when and why they succeed or fail. It lays out a framework for thinking about precedent's force in particular contexts, suggesting both factors to look to-available sources, features of authority, actors and audiences - and lenses to apply - rationalist, jurisprudential, and sociological. What the framework indicates is the need for more in-depth case studies following particular precedents in particular fields that can begin to explain how these factors and accounts intersect, overlap, and compete to produce the practice of international law. This is the next step.

\footnotetext{
${ }^{108}$ Compare Ratner (n 104) 3-4 with Heller (n 101).

${ }^{109}$ See Luban (n 91).
} 